\title{
La ejecución del acuerdo de mediación en asuntos civiles y comerciales. Una revisión impostergable
}

\author{
Eduardo Jequier Lehuedé*
}

\begin{abstract}
RESUMEN
La falta de regulación legal de la mediación de asuntos comerciales y civiles en Chile genera diversas dificultades que inciden en el cumplimiento del acuerdo de mediación, las que se analizan en este trabajo con miras a una propuesta de lege ferenda. Se revisan los principales modelos de mediación de asuntos patrimoniales, en sus extremos de voluntariedad y obligatoriedad, para determinar los efectos que genera cada uno de ellos en la ejecución del acuerdo.
\end{abstract}

Mediación comercial - mediación obligatoria - ejecución del acuerdo

\section{The execution of the mediation agreement in civil and commercial matters. A review that can not be postponed}

\begin{abstract}
The lack of legal regulation of the mediation in commercial and civil matters in Chile generates several difficulties that affect the fulfillment of the mediation agreement, which are analyzed in this work with a view to a lege ferenda proposal. The main models of mediation in patrimonial matters are reviewed, in their extremes of voluntariness and obligatoriness, to determine the effects that generates each of them in the execution of the agreement.
\end{abstract}

Commercial mediation - mandatory mediation - agreement execution

* Licenciado en Ciencias Jurídicas y Sociales, Universidad de Concepción, Chile. Magíster en Derecho de la Empresa, Pontificia Universidad Católica de Chile. Doctor en Derecho, Universidad de Valencia, España. Profesor de Derecho Comercial, Universidad de los Andes. Correo electrónico: ejequier@uandes.cl.

El presente trabajo se realiza en el marco del Proyecto Fondecyt Regular 2015, No 1150087 , titulado "La mediación en asuntos comerciales como instrumento de competitividad y desarrollo empresarial en Chile. Premisas para una propuesta de lege ferenda", del que el autor es investigador responsable, y del Proyecto Anillo de Investigación en Ciencias Sociales CONICYT SOC1 406.

Artículo recibido el 28 de marzo de 2017 y aceptado para su publicación en este número el 23 de julio de 2018. 
No preguntemos si estamos plenamente de acuerdo, sino tan solo si marchamos por el mismo camino. (Johann W. Goethe)

\section{INTRODUCCIÓN}

$\mathrm{U}$

no de los aspectos más controversiales de la mediación de asuntos comerciales y civil-patrimoniales (en adelante e indistintamente "mediación patrimonial" o "mediación empresarial") radica en la eficacia jurídica del acuerdo de mediación, en cuanto factor que determina en último término su efectivo cumplimiento y ejecutabilidad en el orden interno y en el ámbito transfronterizo. Se trata, por lo demás, de una materia vinculada necesariamente a la naturaleza jurídica que se le asigne en cada caso al acuerdo y que depende, a su vez, del modelo de mediación que se quiera seguir: enteramente voluntarista, como el sistema español de la Ley $\mathrm{N}^{\circ} 5 / 2012$; con manifestaciones de obligatoriedad ex lege, como el sistema argentino de la Ley $\mathrm{N}^{\circ} 26.589$; como gestión enteramente desligada del proceso civil, como ocurre también en el señalado modelo español; o, de todas formas, como procedimiento que se desenvuelve en forma más o menos conectada o "anexada" al proceso civil, como ocurre en la mayoría de los ordenamientos comparados y, por esencia, en el mecanismo anglosajón del Court-annexed Mediation.

Pero no solo las legislaciones nacionales se han ocupado en el último tiempo de esta materia. Debido a su complejidad y relevancia, y considerando que de ello depende en buena medida el éxito de la mediación como mecanismo complementario al proceso civil, la ejecución del acuerdo de mediación ha sido abordada también por diversas iniciativas internacionales y supranacionales, plasmadas en instrumentos como la Ley Modelo CNUDMI acerca de Conciliación Comercial Internacional, de 24 de junio de 2002, y la directiva europea No 2008/52/CE de 21 de mayo, "Sobre ciertos aspectos de la mediación en asuntos civiles y mercantiles”. La primera -la Ley Modelo-, si bien está pensada para servir de guía a las legislaciones nacionales en materia de mediación internacional, ofrece no obstante algunas directrices de general aplicación, que bien pueden aplicarse a la mediación patrimonial en el ámbito interno ${ }^{1}$; mientras que la

${ }^{1}$ El art. 14 de la Ley Modelo señala: "Artículo 14. Ejecutoriedad del acuerdo de transacción.

Si las partes llegan a un acuerdo por el que se resuelva la controversia, dicho acuerdo será vinculante y susceptible de ejecución... [los Estados promulgantes podrán incorporar una descripción del medio de ejecución de los acuerdos de transacción o remitirse a las disposiciones que rijan su ejecutoriedad].

Al aplicar el procedimiento de ejecución de los acuerdos de transacción, el Estado promulgante podrá considerar la posibilidad de que dicho procedimiento sea imperativo". Se trata aquí de fijar unas pautas mínimas a seguir por los diversos ordenamientos jurídicos, en el entendido que los acuerdos de mediación, para ser eficaces, deben ejecutarse con facilidad y rapidez. Durante la redacción de la Ley Modelo, en efecto, se observó que "los métodos para agilizar la ejecución diferían enormemente de un ordenamiento jurídico a otro y dependían de tecnicismos propios del derecho procesal interno que no se prestaban fácilmente a la armonización por medio de legislación uniforme”. Por ello, en el artículo 14 la cuestión de la ejecutoriedad, las excepciones a la ejecutoriedad y la designación de los tribunales (u otras autoridades de las que se pudiera 
segunda - la Directiva-, aunque referida también a la mediación transfronteriza en el orden comunitario, fija las pautas para que los Estados miembros, al trasponer sus normas, le asignen fuerza ejecutiva al acuerdo de mediación interno o transnacional ${ }^{2}$, sea directamente o por acto ulterior de homologación judicial ${ }^{3}$.

En el derecho chileno, en cambio, caracterizado por la muy notoria ausencia de normativa legal respecto de mediación de asuntos comerciales y civiles, las dificultades antes descritas se incrementan cuantitativa y cualitativamente.

A partir de la Ley $N^{\circ} 19.698$ (D.O. de 30 de agosto de 2004), el legislador nacional reguló la mediación para resolver determinados asuntos del ámbito familiar, asignándole al acuerdo de mediación el valor de sentencia ejecutoriada (art. 111). Posteriormente, la Ley $\mathrm{N}^{\circ} 19.966$ (D.O. de 9 de septiembre de 2004) incorporó la mediación previa obligatoria en materia de salud (arts. 43 y ss.), asimilando esta vez el acuerdo de mediación a un contrato de transacción (art. 53), a causa del carácter desjudicializado y extrajurisdiccional de este procedimiento de mediación. Más recientemente, el art. 100 bis nuevo de la Ley $\mathrm{N}^{\mathrm{o}} 17.366$, sobre Propiedad Intelectual, incorporado por el art. $1^{\circ} \mathrm{N}^{\circ} 15$ de la Ley $\mathrm{N}^{\circ} 20.435$ (D.O. de 4 de mayo de 2010), establece también un mecanismo de mediación previa obligatoria de muy dudosa constitucionalidad ${ }^{4}$, para aquellos conflictos surgidos ente las asociaciones con personalidad jurídica que representen a usuarios de derechos de autor o conexos -por un lado-y las entidades de gestión colectiva de derechos de autor -por el otro-, acerca de la determinación del monto de las tarifas a pagar por el uso de esos derechos.

Pero más allá de estos ejemplos, aún así, lo cierto es que el legislador ha postergado hasta aquí toda y cualquier referencia a la solución mediada de asuntos civiles y comerciales, circunstancia que genera no pocas dificultades a la hora de definir un régimen de ejecución eficiente e identificable del acuerdo de mediación respecto de asuntos patrimoniales. A ellas apunta precisamente el presente trabajo, cuya vocación de lege ferenda resulta por lo mismo ineludible.

recabar la ejecución de un acuerdo de transacción) "quedan supeditadas al derecho interno aplicable o a disposiciones de la ley por la que se promulgue el régimen de la Ley Modelo" (vid. Naciones Unidas [2004]: Ley Modelo de la CNUDMI sobre Conciliación Comercial Internacional con la Guía para su incorporación al derecho interno y utilización, [Nueva York, publicación de las Naciones Unidas], pp. 55 y 56).

${ }^{2}$ El Considerando $8^{\circ}$ de la Directiva lo aclara expresamente: Las disposiciones de la presente Directiva solo se refieren a los procedimientos de mediación en litigios transfronterizos, pero nada debe impedir que los Estados miembros apliquen dichas disposiciones también a procedimientos de mediación de carácter nacional.

${ }^{3}$ Se refiere a este punto el art. 6, apartados $1^{\circ}$ y $2^{\circ}$, y en términos generales la Consideración $19^{a}$, que señala: "La mediación no debe considerarse como una alternativa peor que el proceso judicial por el hecho de que el cumplimiento del acuerdo resultante de la mediación dependa de la buena voluntad de las partes. Por tanto, los Estados miembros deben asegurar que las partes en un acuerdo escrito resultante de la mediación puedan hacer que su contenido tenga fuerza ejecutiva”.

${ }^{4}$ Se configura aquí un muy cuestionable modelo de Med-Arb ex lege, con una mediación obligatoria de carácter extrajudicial en donde la falta de colaboración de una de las partes se traduce, derechamente, en que la propuesta de tarifas de la otra parte pasa a adquirir, por mandato de ley y sin que exista -obviamente- un acuerdo de mediación, el carácter de equivalente jurisdiccional, que pone término al conflicto con autoridad de cosa juzgada. Semejante arbitrio legal, por esta razón, afecta el derecho a la tutela judicial efectiva, en su vertiente de acceso a la jurisdicción, pues priva a la parte renuente de su derecho a una sentencia oportuna acerca del fondo del asunto controvertido, dictada con todas las garantías. 


\section{Algunas distinciones necesarias: transacción, AVEnimiento y ACUERDO DE MEDIACIÓN}

Una de las primeras consecuencias de la falta de regulación de la mediación patrimonial en Chile se refleja, entre otras, en la diversa tipología jurídica que puede asumir la solución autocompositiva de un conflicto jurídico entre partes. En esencia, la fuente u origen de dicha solución será siempre la voluntad de los sujetos que intervienen en el conflicto, pero la eficacia y ejecutabilidad del acuerdo respectivo dependerá en último término del mecanismo, procedimiento o cauce que se utilice para llegar a él: puramente contractual o transaccional ${ }^{5}$, extrajudicial por mandato de ley, judicial (sea directo por mandato legal ${ }^{6}$ o indirecto por vía de homologación judicial ${ }^{7}$ ) o jurisdiccional ${ }^{8}$.

No nos referiremos a la conciliación, como sistema de solución autocompuesta de conflictos, pues, a diferencia de la transacción, del avenimiento judicial y del acuerdo de mediación, aquella supone necesariamente la intervención de un tercero imparcial que, a diferencia del mediador, propone unas bases de arreglo que las partes pueden o no aceptar, total o parcialmente? . Por ello, cada vez que las partes llegan a un acuerdo en el trámite obligatorio de conciliación contemplado en el art. 262 del CPC, en forma directa y sin una intervención real del juez como conciliador, estaremos en presencia de un avenimiento judicial, mas no de una verdadera conciliación.

${ }^{5}$ Así, por ejemplo, el art. 25.1 de la ley española, No 5/2012, contempla una modalidad de título ejecutivo convencional al señalar que Las partes podrán elevar a escritura pública el acuerdo alcanzado tras un procedimiento de mediación, agregando luego que El acuerdo de mediación se presentará por las partes ante un notario acompañado de copia de las actas de la sesión constitutiva y final del procedimiento, sin que sea necesaria la presencia del mediador.

${ }^{6}$ Es el caso de la ley ecuatoriana de arbitraje y mediación, $\mathrm{N}^{\circ}$ 2006-014, de 17 de diciembre de 2006. Según el art. 47 inc. $4^{\circ}$, El acta de mediación en que conste el acuerdo tiene efecto de sentencia ejecutoriada y cosa juzgada y se ejecutará del mismo modo que las sentencias de última instancia siguiendo la vía de apremio. Una solución similar se contempla en el art. 30 de la ley argentina, $\mathrm{N}^{\circ} 26.589$, que señala: Ejecutoriedad del acuerdo instrumentado en el acta de mediación. El acuerdo instrumentado en acta suscripta por el mediador será ejecutable por el procedimiento de ejecución de sentencia, de conformidad con lo dispuesto por el artículo 500 inciso 4) del Código Procesal Civil y Comercial de la Nación.

${ }^{7}$ Es también el caso del sistema español, cuando el acuerdo de mediación se ha logrado después de iniciado el proceso judicial (art. 25.4 de la Ley N $\mathrm{N}^{\circ}$ 5/2012, en relación con el art. 19.1 de la LEC). Según el citado art. 25.4, Cuando el acuerdo se bubiere alcanzado en una mediación desarrollada después de iniciar un proceso judicial, las partes podrán solicitar del tribunal su homologación de acuerdo con lo dispuesto en la Ley de Enjuiciamiento Civil.

${ }^{8}$ Así por ejemplo, los sistemas coreano y húngaro admiten que las partes, que han llegado a un acuerdo directo, designen a un árbitro para que dicte un laudo conforme a los términos pactados, el que será ejecutado como tal acto jurisdiccional. Al respecto puede consultarse a BARONA Vilar, S., Mediación en asuntos civiles y mercantiles en España. Valencia, Tirant lo Blanch, 2013, pp. 454 y ss.

${ }^{9}$ Esta noción de conciliación en el derecho chileno queda en evidencia en el art. 21 de la Ley No 19.865 , Sobre Financiamiento Urbano Compartido, al señalar en su inc. $5^{\circ}$ que La Comisión Conciliadora buscará la conciliación entre las partes, formulando proposiciones para ello. Si la conciliación no se produce en el plazo de treinta días, cualquiera de las partes podrá solicitarle, en el plazo de diez días, que se constituya en Tribunal Arbitral. Vencido dicho plazo, si no se solicitare la constitución del Tribunal A rbitral, quedará firme la última proposición de la Comisión Conciliadora. Lo mismo ocurre en el art. 35 del DFL MOP N 164, de 1991, sobre concesiones de obra pública. 
Lo anterior, con todo, no significa que durante el trámite de conciliación las partes no puedan llegar a un avenimiento. Por el contrario, el propio art. 263 del CPC parece ponerse en esta situación, al señalar que el juez instará en todo caso por el avenimiento entre las partes, actuando para ello como amigable componedor o, en otros términos, como un mediador cuya función -a diferencia del conciliador- apunta fundamentalmente a guiar y acercar a las partes, para que sean ellas quienes construyan su propia solución. Llama la atención, por tanto, que el Código incluya aquí el "avenimiento" en el título de la "Conciliación”, pues jurídicamente son cosas distintas; pero lo relevante es que para la ley chilena ambas, conciliación y avenimiento, se asimilan a una sentencia judicial ejecutoriada cuando constan en un acta otorgada en conformidad a la ley (art. 267 CPC).

\section{Transacción extrajudicial}

El contrato de transacción está regulado en los arts. 2446 y ss. del Código Civil. El acuerdo, en este caso, es el resultado del ejercicio de la autonomía de la voluntad de las partes respecto de materias disponibles en derecho, sin que sea necesaria la intervención judicial (ex proceso o no) ni la dictación de una sentencia para la plena validez y eficacia de la solución convenida.

En Chile, y considerando nuevamente la ausencia de normativa legal en materia de mediación patrimonial, el andamiaje jurídico natural de una solución mediada será precisamente este: el de un contrato de transacción, sujeto como tal al estatuto propio de todo contrato en cuanto a su validez, efecto relativo y cumplimiento.

Las principales características de esta vía autocompositiva, entonces, que deben tenerse a la vista de cara a la ejecución del acuerdo transaccional resultante de una mediación informal o ad hoc, son las siguientes:

\section{a) La necesidad de concesiones recíprocas}

Tanto la doctrina ${ }^{10}$ como la jurisprudencia ${ }^{11}$ entienden que la transacción debe ser el resultado de una concesión recíproca de derechos y pretensiones entre las partes,

${ }^{10}$ Así por ejemplo Alessandri, al señalar que la transacción "es un contrato por el cual las partes, mediante concesiones recíprocas, celebradas extrajudicialmente precaven un pleito futuro o ponen término a un pleito eventual", siendo indispensable por ende "b) Que las partes se hagan concesiones recíprocas, lo que no supone que las partes renuncien por iguales partes a sus pretensiones, sino que bastaría que cada una de ellas renuncie, aunque sea a una parte de aquellas" (AlessAndri Rodríguez, A., De los Contratos, Santiago, Editorial Jurídica Ediar Conosur Ltda., 1988, pp. 232 y 233).

${ }^{11}$ Por todas, SCS, de 12 de marzo de 2013, casación forma y fondo, Ortiz Faúndez y otros con Corporación Nacional del Cobre de Chile, Rol No 7113-2010: Vigésimo noveno: Que en relación a las reglas del contrato de transacción, que también estima vulneradas el recurrente, es relevante señalar que de acuerdo al artículo 2446 inciso segundo del Código Civil: 'No es transacción el acto que solo consiste en la renuncia de un derecho que no se disputa'. Respecto a este punto, es claro que al no constar contraprestación de parte de los ex trabajadores a cambio de una supuesta 
en donde cada una cede y renuncia en favor de la otra con miras a la solución del conflicto jurídico. De lo contrario, el contrato será nulo.

Sin embargo, esta primera limitante del contrato de transacción es ajena al acuerdo de mediación propiamente tal, que surge de la observancia de un procedimiento de mediación previamente establecido por la ley; ni siquiera cuando resulta de una mediación conectada o anexa al proceso civil. Sobre esto volveremos más adelante.

\section{b) Contrato consensual}

La transacción es un contrato consensual, sin perjuicio de la conveniencia de otorgarla por escrito para fines probatorios. El acuerdo de mediación, en cambio, cuando se logra en el marco de un procedimiento de mediación legalmente establecido, requiere necesariamente del otorgamiento del Acta de acuerdo y, por tanto, de su escrituración con las formalidades legales ${ }^{12}$.

\section{c) Ejecutoriedad}

En conformidad al art. 2460 del C.C., La transacción produce el efecto de cosa juzgada en última instancia.

Pese al tenor de la norma citada, no existe aquí una asimilación jurídica entre el contrato de transacción y la sentencia judicial, sino simplemente una referencia al efecto obligatorio de los respectivos acuerdos entre las partes ${ }^{13}$. No puede ser de otra forma, por lo además, si se considera la muy disímil naturaleza de ambos institutos -contrato y sentencia judicial-, cada uno con su propio estatuto jurídico y régimen de impugnación.

La misma declaración que hace la norma recién citada, con todo, genera la duda en cuanto a si la transacción tiene valor de título ejecutivo, para efectos de su cumplimiento; pues si aquella produce el efecto de cosa juzgada en última instancia, propio de las sentencias

renuncia de acción de responsabilidad civil del empleador derivada de una enfermedad profesional, la transformaría en una mera renuncia de un derecho no disputado.

${ }^{12}$ Así por ejemplo, arts. 15, 32 y 47 de la ley ecuatoriana, $\mathrm{N}^{\circ}$ 2006-014; art. 23 de la ley española, $\mathrm{N}^{\circ}$ 5/2012; art. $1^{\circ}$ de la ley colombiana, $\mathrm{N}^{\circ} 640$ de 5 de enero de 2001; art. 26 de la ley argentina, $\mathrm{N}^{\circ}$ 26.589; y art. 14 de la Ley Modelo UNCITRAL, por mencionar algunos. En Chile, aunque en materia de mediación familiar, el art. 111 de la Ley $\mathrm{N}^{\circ} 19.968$ exige también que el acuerdo de mediación conste en el "acta de mediación”, la que aprobada por el juez tendrá valor de sentencia ejecutoriada.

${ }^{13}$ Así lo ha dicho la CS, al señalar que el texto citado no dispone una equivalencia a un fallo firme; ordena que "La transacción produce el efecto de cosa juzgada en última instancia;...". De esa expresión se desprende que la referencia está dirigida más bien a la obligatoriedad. Incluso, a una conclusión semejante se llega con la regla de la obligatoriedad de los contratos (art. 1545 del Código Civil), una especie de los cuales es la transacción (...). Además, el propio texto agrega que puede anularse conforme a los artículos precedentes, que aluden a la nulidad de los actos y contratos (de modo que no se anulan como las sentencias). De abi que una asimilación plena no ha sido sostenida por la doctrina ni decidida por la jurisprudencia (como puede verse en las obras sobre la materia, antes citadas) (SCS, de 9 de noviembre de 2015, casación, Banco Santander Chile con Francisco González Rodríguez y otros, Rol No 31.719-2014). 
judiciales, bien podría entenderse que la referencia a dicho efecto tiene al menos ese fin, de dar mérito ejecutivo al contrato como tal, cualquiera sea la forma de su otorgamiento.

Sin embargo, debe tenerse en cuenta aquí lo que señala el art. $464 \mathrm{~N}^{\circ} 3$ del Código de Procedimiento Civil, que reconoce como título ejecutivo el acta de avenimiento pasada ante el tribunal competente y autorizada por un ministro de fe o por dos testigos de actuación. Como se dirá infra, el avenimiento no es más que una transacción entre las partes en juicio, que dada con los requisitos que establece la norma recién citada, tiene mérito ejecutivo. Por esta razón, y a contrario, la transacción que no es dada en el contexto de un litigio pendiente, autorizada por un ministro de fe o por dos testigos y homologada por el juez, carece de mérito ejecutivo. Como apunta Corral, con todo, "Si se quiere convenir una transacción que tenga fuerza ejecutiva lo más seguro será otorgarla por escritura pública, cuya copia autorizada está mencionada como título ejecutivo en el art. $434 \mathrm{~N}^{\circ} 2$ del Código de Procedimiento Civil"14.

\section{d) Régimen de validez y cumplimiento}

Como contrato bilateral y oneroso, la transacción se encuentra sujeta al estatuto general sobre formación del consentimiento, nulidad absoluta y relativa (sin perjuicio de las reglas específicas contenidas en el Título XL, del Libro IV, del C.C.) y cumplimiento de las obligaciones, incluida la condición resolutoria tácita del art. 1489 y la exeptio non adimpleti contractus del art. 1552 del C.C.

\section{Avenimiento}

Otra forma de poner término a un conflicto jurídico, cuando ya se ha judicializado, es mediante un acuerdo o "avenimiento" al que las partes llegan sin la intervención del juez, aunque homologado por el mismo. Dicho acuerdo, que bien puede darse en Chile en el marco de una mediación desformalizada seguida en forma independiente y paralela al proceso (mediación ad hoc desconectada), constituye también una forma de transacción que, por existir precisamente un juicio pendiente sobre la materia transada, debe ser puesto en conocimiento del tribunal para que produzca sus efectos.

No se trata aquí, entonces, de un acto puramente procesal, pues su origen es esencialmente volitivo, sustentado en la autonomía de la voluntad de las partes y en el entendido que, si estas son libres para crear, modificar y extinguir relaciones jurídicas acerca de materias disponibles, también lo son para elegir la forma de solucionar los conflictos que surgen de aquellas. Tampoco es estrictamente contractual, pues, a diferencia del acuerdo de mediación ad hoc o desformalizado, el avenimiento se asimila en este caso a la sentencia firme y produce el efecto de cosa juzgada (manifestación exclusiva

${ }^{14}$ Corral TAlciani, H. Disponible en: https://corraltalciani.wordpress.com/2013/05/19/conciliacionavenimiento-y-transaccion/ (Consultado el 21 de febrero de 2017). 
de la función jurisdiccional $)^{15}$, al punto que el Acta que lo contiene constituye título ejecutivo (art. $434 \mathrm{~N}^{\circ} 3 \mathrm{CPC}$ ). Es, en consecuencia, un equivalente jurisdiccional de naturaleza autónoma, aun cuando alguna jurisprudencia ha puesto el énfasis en su rasgo estrictamente jurisdiccional, al considerarlo como un acto jurídico procesal ${ }^{16} \mathrm{y}_{\text {bilateral }}{ }^{17}$.

Las características a destacar en el avenimiento, entonces, de cara a la ejecutividad del acuerdo entre las partes, son las siguientes:

a) En cuanto al contenido material del acuerdo y la necesidad de concesiones recíprocas

Siendo una forma de transacción, en su manifestación o vertiente contractual, el avenimiento judicial sigue la misma regla de aquella en cuanto al contenido material del acuerdo entre las partes, que solo debe abarcar lo que se disputa en el juicio.

Lo propio ocurre con la necesidad de que existan unas concesiones recíprocas, pues si solo una de las partes cede, aceptando en todo el derecho contrario, estaremos ante un desistimiento de la demanda (si quien renuncia es el demandante) o de un allanamiento a la misma (si el que cede es el demandado); pero no ante un avenimiento propiamente tal.

\section{b) Cumplimiento, cosa juzgada y desasimiento}

Según el art. $434 \mathrm{~N}^{\circ} 4$ del CPC, el acta de avenimiento dada con los requisitos legales constituye título ejecutivo.

Asimismo, pese a su origen convencional y a diferencia del contrato de transacción, el avenimiento homologado por el juez constituye un equivalente jurisdiccional, asimilado en sus efectos - que no en su fuente- a la sentencia judicial y al efecto de cosa

15 Así lo señala la Corte de Apelaciones de San Miguel: Tercero: Que esta causal dice relación con la excepción de cosa juzgada promovida de contrario, la que fue acogida, sobre la base de considerar que concurrían en la especie los requisitos del artículo 177 del Código de Procedimiento Civil, a saber, la triple identidad de personas y cosa pedida respecto de lo cual no hay discusión y de idéntica causa de pedir entre la causa RIT 02262014 , terminada por Avenimiento aprobado por el tribunal, (...). Cuarto: Que el fallo impugnado considera que entre ambas causas existe la misma causa de pedir, esto es, el fundamento inmediato del derecho deducido en juicio amén de identidad legal de partes $y$ de pretensión, esto es, indemnización del daño emergente, lucro cesante y daño moral, pues en ambas causas se invoca el accidente acaecido el 14 de febrero de 2014. Se tiene presente, además, que la calificación de "accidente del trabajo" es de fecha anterior al avenimiento al que arribaron las partes $y$, por ende, supone que era un becho conocido por lo menos para el actor (SCA de San Miguel, de 25 de noviembre de 2016, recurso de nulidad laboral, Carlos Pino Cádiz con Sociedad Industrial Romeral S. A., Rol No 330-2016).

${ }^{16}$ Así lo ha sostenido la Corte Suprema, al señalar: DÉCIMO: Que seguidamente, es menester consignar, para descartar la transgresión al artículo 2446 del Código Civil, que la tercerista funda su demanda incidental en un juicio seguido ante el Juzgado de Cobranza Laboral y Previsional de Santiago, bajo el Rit J-2351-2010, en base a un título ejecutivo que invoca, constituido por el avenimiento judicial alcanzado por las partes en el juicio laboral ordinario Rol $N^{\circ} 843-2009$, seguido ante el $9^{\circ}$ Juzgado Laboral de Santiago, esto es, un acto jurídico procesal que no puede confundirse con el contrato de transacción regulado en la citada disposición legal; (SCS, de 21 de octubre de 2013, casación fondo, Banco Santander Chile con Iturra Navarro Antonio y otros, Rol N ${ }^{\circ} 1753-2013$ ).

${ }^{17}$ Por todas, SCS, de 25 de mayo de 2016, casación, Luis Hernández Rosales con Cesar Rodríguez Esquivel, Rol N ${ }^{\circ} 18.822-2015$. 
juzgada; o como dice la Corte Suprema, (...) es un acto procesal bilateral que contiene un acuerdo al que arriban las partes en juicio, debidamente autorizado por el tribunal, el que reviste el carácter de equivalente jurisdiccional. De esta forma, el avenimiento constituye un medio diferente de la jurisdicción, capaz de solucionar legítimamente un litigio. Es, por cierto, un acto jurídico procesal que, sin estar asociado a las fases de conocimiento, juzgamiento y ejecución propias de la jurisdicción, culmina con el mismo efecto final de una sentencia definitiva: el de cosa juzgada ${ }^{18}$.

Por lo anterior, y a diferencia -nuevamente- de la transacción extrajudicial, obtenida directamente por las partes o en el marco de una mediación ad hoc, el avenimiento es susceptible de ser cumplido por los mismos mecanismos de ejecución de las sentencias judiciales, arts. 232 y ss. del CPC. Así lo ha dicho también la jurisprudencia, cuyo criterio compartimos:

CUARTO: Que el artículo 232 del Código de Procedimiento Civil, que se contiene en el Título XIX, del Libro I de dicho estatuto, 'Disposiciones Comunes a Todo Procedimiento', prescribe a la letra: (...).

QUINTO: Que, luego de lo dicho, estos sentenciadores consideran que a la luz de una interpretación sistemática y teleológica de la normativa precedentemente citada, constituyendo el avenimiento aprobado por resolución judicial de 3 de noviembre de 2014 un equivalente jurisdiccional a la sentencia definitiva ejecutoriada que debió poner fin a la instancia resolviendo la cuestión o asunto que fue objeto del juicio, al que el legislador reconoce expresamente, además, mérito ejecutivo, no existe razón alguna de texto legal que impida a aquel en cuyo favor se ha declarado un derecho en el juicio para que solicite el cumplimiento de lo resuelto con autoridad de cosa juzgada ante el mismo tribunal que llevó a cabo la tramitación del proceso y que lo tuvo por aprobado, siempre que la ejecución se solicite dentro del plazo de un año contado desde que ella se hizo exigible ${ }^{19}$.

Por otra parte, la asimilación del acta de conciliación o de avenimiento a la sentencia ejecutoriada lleva consigo el efecto consecuencial del desasimiento del tribunal que lo autoriza, el que no puede luego alterarlo. Así lo dijo la Corte de Apelaciones de Concepción (aunque asimilando erróneamente la conciliación con el avenimiento):

3.- Que, la conciliación (sinónimo de avenimiento) es una manera de terminar un pleito o litigio civil y equivale y substituye el fallo judicial, tiene la misma significación que la sentencia y ello queda de manifiesto en la disposición del artículo 267 del Código de Procedimiento Civil, (...).

4.- Que identificada la conciliación como sentencia firme o ejecutoriada para todos los efectos legales, se produce, además de la acción y excepción de cosa juzgada, otro importante efecto; el desasimiento del tribunal.

18 SCS, de 25 de mayo de 2016, casación, Luis Hernández Rosales con Cesar Rodríguez Esquivel, Rol $\mathrm{N}^{\circ} 18822-2015$.

${ }^{19}$ SCA de Santiago, de 7 de agosto de 2015, apelación, Sociedad Chilena del Derecho de Autor con Inversiones Luis Guillermo Cordovez Avila Hoteles E.I.R.L., Rol No 4243-2015. 
En virtud de este principio (desasimiento) consagrado en el artículo 182 inciso primero del Código de Procedimiento Civil, el tribunal que intervino en el avenimiento no puede modificarlo ni alterarlo en manera alguna.

5.- Que de todo lo dicho fluye con toda claridad que la juez, que irrumpió en el proceso para anular de oficio el avenimiento y el comparendo todo en que se arribó el acuerdo conciliatorio (...) no ha podido desde una consideración estrictamente procesal, obrar como lo bizo quebrantando todos los principios legales que el juez está obligado a respetar, regresando un asunto concluido al campo de la incerteza.

(...) Su decisión anulatoria es írrita por donde quiera que se le mire, por lo que habrá de privársela de efectos ${ }^{20}$.

Por último, y siempre como consecuencia del efecto de cosa juzgada que la ley le asigna al avenimiento judicial, los acuerdos contenidos en el mismo tampoco pueden ser alterados o modificados por una sentencia posterior, judicial o arbitral:

Sexto. (...) si al juicio arbitral se puso fin en virtud de una conciliación en la que se pagó por una de las partes una suma de dinero como única indemnización por los hechos y/o circunstancias que habian motivado el compromiso, otorgándose las partes el más amplio, completo y total finiquito en relación a esos mismos hechos, es evidente que la sentencia que acoge la demanda en la que se pretende indemnizar perjuicios por responsabilidades derivadas de la aplicación de los contratos Eroles 1 y Eroles 2 infringe la autoridad de cosa juzgada que, de conformidad con lo dispuesto en el artículo 267 del Código de Procedimiento Civil, tiene el acta en que se deja constancia de los términos de la conciliación, en tanto esta, de acuerdo a esa norma, debe estimarse como sentencia ejecutoriada para todos los efectos legales ${ }^{21}$.

c) Nulidad procesal y nulidad sustancial

Otra diferencia entre la transacción extrajudicial y el avenimiento judicial radica en el estatuto jurídico de anulación e incumplimiento, aplicable a este último.

En cuanto a la anulabilidad del avenimiento judicial, debe considerarse en primer término su doble filiación, contractual y procesal ${ }^{22}$. Como acto procesal, y como se dijo supra, el avenimiento aprobado por el juez produce el efecto de cosa juzgada y origina el desasimiento del tribunal que lo aprobó, de manera que este no puede anularlo posteriormente. Como transacción, en cambio, es susceptible de ser anulado total o parcialmente

${ }^{20}$ SCA de Concepción, de 10 de mayo de 2007, apelación, Rol No 571-2007.

${ }^{21}$ SCS, de 6 de noviembre de 2007, casación, Construcción y Montajes Eroles Limitada; Luis Monso Díez; Jorge Monso Díez; con Codelco Chile División Andina, Rol No 1114-2007.

${ }^{22}$ Según el art. 25.4. de la ley española No 5/2012, que sigue una concepción esencialmente contractualista del acuerdo de mediación, Contra lo convenido en el acuerdo de mediación solo podrá ejercitarse la acción de nulidad por las causas que invalidan los contratos". Tratándose de la transacción judicial, en cambio, la jurisprudencia ha señalado que esta "tiene una naturaleza dual, ya que, manteniendo su carácter sustantivo, la aprobación judicial le confiere un carácter procesal como acto que pone fin al proceso, con el efecto de hacer posible su ejecución como si se tratara de una sentencia (arts. 1816 CC y 517.3 LEC) (STS español, de 5 de abril de 2010, rec. 2371/2005). 
en conformidad con el estatuto común de nulidad sustancial del CC, en juicio de lato conocimiento. Así lo dijo la Corte de Apelaciones de La Serena, en una antigua sentencia:

Que en lo principal del escrito los abogados de las partes acordaron poner término al juicio, para todos los efectos legales, acuerdo que fue aprobado por el Tribunal a quo;

Que el acuerdo de voluntades a que se ha hecho mención en el fundamento precedente, reviste un doble carácter: es un contrato, porque tal acuerdo lo producen las partes y es una actuación judicial, porque se realiza en una actividad procesal;

Que, como actuación judicial, el acuerdo mencionado importa una forma excepcional de poner término al juicio, constituye un sustituto del fallo y como tal, una vez aprobado por el Tribunal, no podría, por haberse finiquitado la litis, reclamar por la vía incidental los defectos de que pudiere adolecer, ya que todo incidente, como cuestión accesoria del juicio mismo, debe alegarse in limine litis;

Que en cambio, como contrato, el referido convenio está sujeto a las formalidades consignadas en el Código Civil y por tanto, los vicios o defectos de que pudiere adolecer solo son susceptibles de ser reclamados en juicio de lato conocimiento y fundados en las causales relacionadas en el Código Civil; ${ }^{23}$.

En similares términos se pronuncia el Tribunal Supremo español:

(...) la imposibilidad de replantear las cuestiones transigidas no implica que la transacción sea invulnerable, ya que puede impugnarse su validez y eficacia, dejándola sin efecto y reavivando la situación jurídica anterior. La interpretación del artículo 1816 CC ha de bacerse sin mengua de la naturaleza contractual propia de la transacción ${ }^{24}$.

d) Resolución por incumplimiento del avenimiento judicial

Otra notoria diferencia entre la transacción extrajudicial y el avenimiento judicial, derivada de su naturaleza convencional-procesal, consiste en que este último, por el componente procesal que lo integra, no es susceptible de ser resuelto en caso de incumplimiento. Así lo ha dicho también la jurisprudencia:

OCTAVO: Que no obstante el carácter contractual del documento en estudio, en cuanto contiene un acuerdo bilateral que generó obligaciones recíprocas, su incumplimiento no puede dar lugar a la acción resolutoria intentada, pues el avenimiento, como mecanismo autocompositivo de solución del conflicto, está destinado a poner término al litigio, finalidad que no se satisface con la resolución del pacto sino con el estricto cumplimiento de las obligaciones allí estipuladas (...) a este contrato, por su naturaleza y finalidad, el

${ }^{23}$ SCA de La Serena, de 22 de mayo de 1975, René Tapia Tapia contra Orlando Cortés Abarca (sin registro de Rol). Disponible en Westlaw Chile, Id. N ${ }^{\circ}$ CL/JUR/7/1975 (Consultado el 23 de febrero de 2017).

${ }^{24}$ STS español de 8 de julio de 1999, rec. 3614/1994. 
legislador le otorgó un carácter especial: el de equivalente jurisdiccional, conforme al artículo 267 del Código de Procedimiento Civil. Luego, el avenimiento reviste el carácter de tal por tratarse de un acuerdo que lograron directamente las partes, en virtud del cual pusieron término a su conflicto pendiente de resolución judicial, expresándoselo así al tribunal que conocía de la causa; acuerdo al cual el legislador le otorgó el carácter de cosa juzgada, lo que impide a sus otorgantes solicitar la resolución del mismo en el caso de incumplimiento de las obligaciones en él contenidas, y determina consecuencialmente la improcedencia de la acción de resolución de contrato ${ }^{25}$.

\section{Acuerdo de mediación}

Retomamos aquí lo señalado supra: el ordenamiento jurídico chileno no cuenta con normativa legal en materia de mediación de asuntos comerciales y civil/patrimoniales. Cualquier acuerdo que surja en el marco de un procedimiento desformalizado o ad hoc de mediación, por tanto, se traducirá necesariamente en un contrato de transacción, que en el mejor de los casos podrá otorgarse por escritura pública o, si existe paralelamente un juicio pendiente acerca del mismo conflicto, podrá plasmarse en un acta de avenimiento judicial, con las consecuencias y alcances ya descritos.

El acuerdo como tal, por esta razón, deja de formar parte del procedimiento de mediación y asume, en cambio, una fisonomía jurídica desconectada de su origen. Dicho de otra forma, no existirá aquí un "acuerdo de mediación” con fisonomía propia, resultante de un procedimiento de mediación que, por estar regulado en la ley, incorpora el acuerdo como parte integrante del mismo y con efectos también propios ${ }^{26}$. Por el contrario, el acuerdo se materializará en un acto jurídico de naturaleza variable (transacción extrajudicial o avenimiento), mientras que la mediación que le antecede no será más que un reflejo pálido de su génesis, sin mayor trascendencia jurídica. De aquí, en todo caso, la

25 SCS, de 25 de mayo de 2016, casación, Luis Hernández Rosales con Cesar Rodríguez Esquivel, Rol $\mathrm{N}^{\mathrm{o}} 18822-2015$.

${ }^{26}$ Como apunta BARONA, cada ordenamiento jurídico debe decidir qué valor y efectos le asigna al acuerdo de mediación, más o menos expansivo o incisivo, con variables legales que pueden ser enormes. El acuerdo -dice- "se identifica con el acto final del procedimiento, cuando se hace referencia a acuerdo como última etapa de la mediación (...), materializándose en un documento que será firmado por todas las partes (...) cuya validez, insistimos, vendrá legalmente definida” (Barona, S. [n.7], p. 437. En contra Senés, quien estima que "el acuerdo no forma parte del procedimiento de mediación, pero como resultado posible de este, su validez depende de que el procedimiento se haya desarrollado conforme a las exigencias de la Ley de Mediación” (SEnÉs Motilla, C., "El acuerdo de mediación y su ejecución”, en López, F. y GARAu, F. [coord.], Mediación en materia civil y mercantil. Valencia, Tirant lo Blanch, 2014, p. 290). Esta última tesis, que no compartimos, solo puede plantearse -en todo caso- en un contexto en el que el acuerdo de mediación tiene una naturaleza contractual, como es precisamente el de la actual ley española $N^{\circ} 5 / 2012$ (sin perjuicio de la posibilidad de homologación judicial a que se refiere su art. 25.4); pero no en un escenario de mediación conectada al proceso civil, como es por ejemplo el sistema del court annexed mediaton, el que se regula en la ley argentina ya mencionada - por nombrar alguna- e incluso en el caso de la ley chilena en materia de mediación familiar (art. 111 inc. $2^{\circ}$ Ley $\mathrm{N}^{\circ}$ 19.968). 
necesidad de distinguir aun en Chile entre la transacción extrajudicial (o desconectada del proceso) y el avenimiento (o transacción conectada al proceso).

Muy distinta es la realidad en aquellos ordenamientos comparados -actualmente la mayoría- que han regulado la mediación en este ámbito patrimonial, estableciendo unos principios generales, unas normas y garantías al menos básicas de procedimiento y, en lo que aquí interesa, un escenario jurídico en donde el acuerdo y sus efectos gozan de autonomía propia.

\section{LA EJECUCIÓN DEL ACUERdo DE MEdiaCión. DEl SISTEMA OBLIGATORIO} AL MODELO DE MEDIACIÓN POR INICIATIVA DE LAS PARTES

La instalación de la mediación como una práctica social que sea reconocida y sustentable depende en buena medida de la opción que se haga en cuanto al modelo a seguir ${ }^{27}$. En ese contexto, sin embargo, los matices a considerar van desde la plena voluntariedad para las partes del conflicto patrimonial hasta una obligatoriedad genérica impuesta por el legislador; y desde la total desvinculación del procedimiento de mediación con el proceso civil hasta su entera dependencia y conexión con este último, antes o durante el mismo.

En este punto, los sistemas normativos comparados que se han ocupado de regular legalmente la mediación de asuntos patrimoniales ofrecen un variado elenco de modelos y sistemas, panorama que se explica por cuanto, a diferencia de los mecanismos heterocompositivos, en la mediación afloran -e influyen- los más variados elementos que conviven en la esfera del conflicto (explícitos e implícitos, objetivos y subjetivos, racionales e irracionales); y todos ellos bien condimentados con intereses y motivaciones personales, emociones, valores, etc. No yerra Dupuis, por tanto, cuando afirma que "muchas veces el conflicto es más grave en la mente de los hombres que en la realidad"28; ni lo hace Fisher al señalar que cualquier intento de mediación "debe mejorar, o por lo menos no deteriorar, la relación de las partes" 29 .

\section{Una aclaración preliminar: la mediación obligatoria y su incardinación en el ordenamiento constitucional chileno}

La mediación tiene su fuente en la libertad y en la autonomía de la voluntad de las partes enfrentadas en un conflicto, lo que se traduce en que estas no están obligadas

\footnotetext{
${ }^{27}$ Acerca de los distintos sistemas comparados de mediación puede consultarse nuestro trabajo $L a$ mediación como alternativa de solución de los conflictos empresariales en Chile. Razones y mecanismos para su regulación, en Revista de Derecho (Universidad Austral de Valdivia, 2016), vol. 29, No 1, pp. 102 y ss.

${ }^{28}$ Dupuis, Juan Carlos, Mediación y Conciliación (Buenos Aires, Abeledo Perrot), 2001, p. 33.

${ }^{29}$ Fisher, Roger y URY, William, ;Sí, de acuerdo! Cómo negociar sin ceder, $2^{\mathrm{a}}$ ed., $4^{\mathrm{a}}$ reimpresión, (Bogotá, Norma), p. 4.
} 
a someter sus asuntos a mediación y menos a llegar a un acuerdo en ese marco, como alternativa única de solución del conflicto.

Sin embargo, nada impide que la ley pueda imponer también la mediación previa para asuntos comerciales, sea de manera directa y como requisito de procesabilidad ${ }^{30}$ de determinadas acciones, o por vía indirecta al conferirle al juez la facultad de sugerir o imponer la mediación cuando lo estime conveniente. Tal imposición no afecta el derecho fundamental de tutela judicial efectiva, en su vertiente de acceso a la jurisdicción, sino que abre simplemente un cauce extrajudicial de solución del conflicto, que bien puede ser estimulado por el Estado mediante la fórmula obligatoria previa. Así lo entiende precisamente el art. $3^{\circ}$ de la Directiva 2008/52/CE ya mencionada, que define la mediación como un procedimiento estructurado, sea cual sea su nombre o denominación, en que dos o más partes en un litigio intentan voluntariamente alcanzar por sí mismas un acuerdo sobre la resolución de su litigio con la ayuda de un mediador. Este proceso (agrega la misma disposición) puede ser iniciado por las partes, sugerido u ordenado por un órgano jurisdiccional o prescrito por el Derecho de un estado miembro.

De especial interés resulta en este sentido la sentencia dictada por el TC, de fecha 10 de julio de 2012. Allí, y conociendo de una acción de inaplicabilidad por inconstitucionalidad presentada por un particular en el marco de un proceso judicial por supuesta negligencia médica todavía pendiente, el Tribunal Constitucional ha declarado -con voto disidente- la constitucionalidad del mecanismo de mediación obligatoria que establece el art. 43 de la Ley No 19.966, sobre "Régimen de Garantías de Salud".

Debemos reconocer, ante todo, que la mediación obligatoria y los problemas dogmáticos que genera, tanto en el caso de la Ley $\mathrm{N}^{\circ} 19.966$ como en aquellos contemplados en materia de familia, son siempre los mismos y han sido planteados no solo en nuestro medio, sino también en aquellos ordenamientos jurídicos comparados que la contemplan en términos más o menos similares. Respecto de este punto pueden encontrarse variadas opiniones, cuyos extremos comunes contraponen por un lado el libre acceso a la jurisdicción -como lo planteó precisamente el recurrente de inaplicabilidad-y, por el otro, el intento de paliar y evitar procesos inútiles, dando la opción al demandado para que subsane lo que haya que subsanar y al demandante para que revise y ajuste su pretensión.

Sin embargo, la gran novedad que trae la sentencia referida radica, a nuestro juicio, en que el Tribunal Constitucional descarta, expresamente y por primera vez, todo sesgo de inconstitucionalidad en la institución de la mediación obligatoria como tal, criterio que resulta perfectamente extrapolable al ámbito de los conflictos empresariales aun

${ }^{30}$ En el caso australiano, por otro ejemplo, diversas legislaturas exigen a las partes que antes de someter un asunto a la jurisdicción estatal, se sometan a algún mecanismo alternativo de solución de conflictos. Así lo señala -v.gr. - la sección 4 de la Civil Dispute Resolution Act, del 2011, que requiere la realización previa de esfuerzos o pasos seguros (genuine steps) para resolver el conflicto; o la Civil Procedure Act de Nueva Gales del Sur, del 2005 (Part 2A), que exige haber tomado providencia o pasos razonables (reasonable steps) en este mismo sentido. 
cuando estos, a diferencia de los anteriores, se sitúen en un contexto de materias disponibles en derecho. Dijo en este punto el TC:

VIGESIMOSEXTO: (...) la mediación no impide el acceso a la justicia ni tampoco obstaculiza la reparación que se persigue. No impide el acceso a la justicia porque, como señala el inciso final del artículo 45 de la Ley $N^{0} 19.966$, durante el plazo que dure la mediación se suspenderá el término de prescripción, tanto de las acciones civiles como de las criminales a que bubiere lugar. Así, el reclamante no ve cercenada la posibilidad de que se haga justicia en su favor, pudiendo recurrir a la justicia con posterioridad al desarrollo de un proceso de mediación que ha fracasado.

Por la misma razón anterior, la exigencia de acudir en forma previa a la mediación, antes de deducir las acciones judiciales que procedan, no impide la reparación que se pretende, pues la mediación tiende precisamente a ello, por cierto, si existe debido fundamento. Si aun existiendo ese fundamento, la mediación fracasa, queda igualmente abierto el camino para deducir las acciones judiciales que procedan ${ }^{31}$.

La posibilidad de forzar el procedimiento de mediación, entonces, no vulnera el derecho a la tutela judicial efectiva, pues deja abierta la vía judicial en todo caso; o, dicho de otra forma, lo obligatorio aquí no es mediar, sino someterse al procedimiento de medición. Todavía más, la fórmula obligatoria de la mediación ha sido vista como una manera de acortar la brecha que existe entre esta última y la vía jurisdiccional, que reúne sin duda las preferencias a la hora de optar por un cauce de solución de los conflictos patrimoniales. Tal escenario, que obedece principalmente a la desconfianza o desincentivo que genera la poca información disponible entre las empresas y sus abogados, a la falta de capacitación de los grupos de interés (abogados, mediadores, empresarios, jueces), o a ambas, hunde a su vez sus raíces en un fenómeno de mayor profundidad y complejidad, como es la ausencia generalizada de políticas públicas que posicionen a la mediación como un mecanismo que atañe no solo al interés de las partes en conflicto, sino también -y principalmente-al interés público.

\section{Obligatoriedad y voluntariedad en el derecho comparado. su incidencia en el cumplimiento} del acuerdo de mediación

No es esta la oportunidad de analizar en detalle cada uno de los sistemas de mediación "en ejercicio" en el ámbito comparado, pues ello, amén de innecesario, resulta hasta pretensioso debido a la variada gama de alternativas posibles. Sin embargo, y como se adelantó supra, cada uno de esos sistemas particulares responde a la opción concreta por un determinado modelo de mediación, en donde el Estado puede desempeñar una función más o menos intervencionista dependiendo del grado de libertad que se le reconozca a las partes en cuanto a la decisión de someterse -o no- a dicho mecanismo.

${ }^{31}$ STC, Recurso de inaplicabilidad, Rol N 2042-11-INA. 
En un extremo, sistemas como el argentino o el italiano ${ }^{32}$ contemplan la mediación previa al proceso civil en términos obligatorios y como requisito de procesabilidad de la acción; en un estadio intermedio, sistemas como el esloveno y el holandés ${ }^{33}$ han preferido una obligatoriedad atenuada, dándole la iniciativa al juez para llamar a las partes a mediación obligatoria; mientras que en el extremo opuesto están aquellos ordenamientos que privilegian la plena voluntariedad, como es el caso español ${ }^{34}$.

En lo que concierne a la ejecución del acuerdo, en consecuencia, cada una de las alternativas descritas genera concretas consecuencias jurídicas, las que pueden resumirse del modo siguiente:

\section{A) Mediación obligatoria}

Se trata aquí de una manifestación del poder del Estado plasmada en una norma legal imperativa, que obliga a someterse a mediación como una forma efectiva para romper el hielo entre partes hostiles o simplemente desinformadas, que de otra forma jamás llegarían a la mediación como una opción procedimental alternativa. Esta fórmula, a su vez, puede presentarse de manera vinculada al proceso civil o enteramente desconectada del mismo; y a su vez puede tener un alcance general, para todos los asuntos de índole patrimonial salvo excepciones (caso argentino), o circunscrito a ciertos y determinados asuntos, señalados concretamente en la ley ${ }^{35}$.

${ }^{32}$ El art. 5.1 del Decreto Legislativo 28, de 4 marzo 2010, señalaba en este sentido: 2. Chi intende esercitare in giudizio un'azione relativa ad una controversia in materia di condominio, diritti reali, divisione, successioni ereditarie, patti di famiglia, locazione, comodato, affitto di aziende, risarcimento del danno derivante dalla circolazione di veicoli e natanti, da responsabilità medica e da diffamazione con il mezzo della stampa o con altro mezzo di pubblicità, contratti assicurativi, bancari e finanziari, e' tenuto preliminarmente a esperire il procedimento di mediazione (...). L'esperimento del procedimento di mediazione e' condizione di procedibilità della domanda giudiziale. Esta disposición, sin embargo, fue declarada como ilegítima por la Corte constitucional italiana, por sentencia N ${ }^{\circ} 272 / 2012$, de 24 de octubre de 2012, lo que se tradujo en una suspensión temporal de dicha disposición, entre 2012 y 2013. La referida sentencia de tradujo, finalmente, en una reforma de la mediación obligatoria, reincorporada mediante la Ley $\mathrm{N}^{\circ}$ 98, de 2013, que contempló tres tipos de obligatoriedad: la que deriva del pacto de las partes; la que impone el juez durante el procedimiento; y la que se exige ex lege y de manera previa al inicio del proceso civil.

33 Cfr. Herrera de las Heras, R., "La mediación obligatoria para determinados asuntos civiles y mercantiles", en Revista InDret (N $\mathrm{N}^{\circ}$ 1-2017), p. 9. Disponible en http://www.indret.com/pdf/1282.pdf (Consultada el 16 de marzo de 2017).

${ }^{34}$ Parte de la doctrina española ha insistido, sin embargo, en la necesidad y conveniencia de incorporar la mediación previa obligatoria de asuntos civiles y mercantiles en España. Por todos Magro SERVET, V., "Análisis sobre medidas necesarias de desarrollo legal y reglamentario de la Ley No 5/2012 de mediación civil y mercantil para el éxito del sistema”, en Práctica de Tribunales (No 2254-948X, 12 de marzo de 2013).

${ }^{35}$ Es por ejemplo lo que ocurre en Australia con la Farm Debt Mediation Act, de 1994, y concretamente con su "Reglamento de Mediación en Deudas Agrícolas", del mismo año, que estableció un régimen de mediación para la resolución de disputas por deudas relacionadas con el desarrollo de proyectos o actividades agrícolas. El acreedor del crédito, normalmente bancos e instituciones financieras, no puede tomar ninguna acción para hacer exigible la deuda del agricultor, sin antes notificarle de su intención de cobro y de la posibilidad de mediar. El acreedor puede eximirse de esta obligación, mediante un certificado que acredite que se ha realizado ya una mediación satisfactoria, en la que el agricultor rechaza la propuesta de mediación, 
a) Mediación obligatoria conectada o anexa al proceso civil

En este caso, la obligatoriedad de la mediación se traduce por regla general en que el acuerdo respectivo, surgido en el marco de un procedimiento conectado o anexo al proceso civil, será considerado como parte del procedimiento mismo y, por esta razón, un equivalente jurisdiccional de naturaleza autónoma, que se ejecutará del mismo modo en que lo son las sentencias judiciales. Es, precisamente, lo que ocurre con el acuerdo de mediación familiar regulado en la Ley $\mathrm{N}^{\circ} 19.968$ y, concretamente, con el Acta que lo contiene, a la que se le asigna el valor de sentencia ejecutoriada (art. 11 inc. $2^{\circ}$ ); y es también la solución que contemplan legislaciones extranjeras como la argentina ya mencionada, la ecuatoriana ${ }^{36}$ y la nicaragüense ${ }^{37}$, por nombrar algunas del ámbito latinoamericano.

La adopción del modelo obligatorio, a su vez, involucra para el legislador otras tantas opciones o decisiones complejas:

i) Debe determinar, en primer término, el momento en que se debe realizar la mediación, para que sea más efectiva de cara a la solución del conflicto.

Parece evidente que la búsqueda del mejor momento para mediar es impredecible, ya que depende de las circunstancias, partes y en definitiva del caso particular en conflicto $^{38}$. Sin embargo, siempre es posible identificar ciertas características de la disputa que indicarán si la mediación tiene más posibilidades de ser exitosa en una determinada etapa del conflicto; pero ello, sin embargo, supone una particular habilidad del legislador para generalizar en categorías de disputas, sin que existan por lo mismo garantías de acierto en ese ejercicio de discriminación.

De aquí, pues, que algunos ordenamientos como el chileno -en materia de familiay el argentino - para todos los conflictos civiles y comerciales- opten por someter a las partes a mediación en una etapa temprana del conflicto, antes de que este se judicialice e incluso como requisito previo de procesabilidad. Otros, en cambio, le confieren al juez la facultad de derivar a las partes a mediación durante el proceso, como ocurre en general

o que aquel intentó mediar de buena fe por un período de tres meses. Lo propio ocurre en la legislación de New South Wales, en materia de conflictos de arrendamiento, a menos que la propia Corte resuelva que la mediación no es una alternativa en el caso puntual (Retail Leases Act, de 1994);

${ }^{36}$ El art. 47 de la Ley de Arbitraje y Mediación de Ecuador, No 2006-014 de 17 de diciembre de 2006, señala: El acta de mediación en que conste el acuerdo tiene efecto de sentencia ejecutoriada y cosa juzgada y se ejecutará del mismo modo que las sentencias de última instancia siguiendo la vía de apremio, sin que el juez de la ejecución acepte excepción alguna, salvo las que se originen con posterioridad a la suscripción del acta de mediación. Si el acuerdo fuere parcial, las partes podrán discutir en juicio únicamente las diferencias que no han sido parte del acuerdo.

37 Art. 20 de la Ley de Mediación y Arbitraje de Nicaragua, No 540 de 25 de mayo de 2005: La ejecución de un acuerdo de mediación, en caso de incumplimiento, se solicitará ante el Juzgado de Distrito competente y se realizará con las reglas establecidas en el Título XXVI, Capítulo IV, Artículos 1996 y siguientes del código de Procedimiento Civil de la República de Nicaragua.

${ }^{38}$ Un interesante estudio sobre este aspecto puede encontrarse en Bergin, P. A., The Objectives, Scope and Focus of Mediation Legislation in Australia, conferencia presentada en el congreso internacional Mediation First, organizado por el Hong Kong International Arbitration Centre y el Hong Kong Mediation Council (Hong Kong, 11 de mayo de 2012). Disponible en: http://www.austlii.edu.au/au/journals/NSWJSchol/2012/24. pdf (consultado el 23 de marzo de 2017). 
con el sistema de Court-annexed Mediation ${ }^{39}$; y otros como el modelo brasileño ${ }^{40}$ o el inglés ${ }^{41}$, entregan la iniciativa a las partes en una etapa temprana o incluso posterior del juicio, con una intervención más o menos gravitante del juez en cuanto a la necesidad de la mediación y su efectiva realización.

ii) Debe definir, además, qué tipo de materias son las que se someterán necesariamente a mediación. La tarea, nuevamente, resulta compleja si se considera la gran diversidad de características y efectos que presentan los conflictos respecto de asuntos comerciales y civiles, tanto en una vertiente jurídica - material y subjetiva- como en sus repercusiones económicas para las partes y para el país en términos agregados. Por ello, las opciones son también variadas en este punto, aunque coincidentes con las ya enunciadas, pues van desde el mandato legal genérico, para todos los conflictos de este orden, hasta la atribución que se le confiere al juez o a las partes para optar por este camino alternativo ${ }^{42}$.

\section{b) Mediación obligatoria desconectada del proceso civil}

En este esquema, la ley impone la mediación de manera desvinculada del proceso civil, situándola en los extramuros del ámbito jurisdiccional. El acuerdo, en estos casos, tendrá necesariamente una naturaleza contractual de carácter transaccional, con las consecuencias ya apuntadas. Es, precisamente, el sistema de mediación regulado en la Ley $\mathrm{N}^{\circ} 19.966$, ya citada, la que por una parte fuerza la mediación previa ante el Consejo de Defensa del Estado ${ }^{43}$, como requisito de procesabilidad de la acción contra los prestadores

${ }^{39}$ Acerca de este sistema véase JEQUIER LEHUEDÉ, Eduardo, "La mediación como alternativa de solución de los conflictos empresariales en Chile. Razones y mecanismos para su regulación”, en Revista de Derecho (Valdivia) (Universidad Austral de Chile, Vol. XXIX, No 1, junio 2016), pp. 108 y ss.

$40 \mathrm{El}$ art. 319 del nuevo Código Procesal Civil brasileño, que regula el contenido de la demanda, establece que en ella el demandante debe indicar si opta o no por una audiencia de conciliación o mediación. En la afirmativa, el art. 334 del mismo código obliga al juez a citarla. La misma norma señala, además, que la no comparecencia y cooperación de las partes constituye un "atentado a la dignidad de la administración de justicia”, sancionada con multa.

${ }^{41} \mathrm{El}$ art. 26.4 de las Civil Procedure Rules establece que cualquiera de las partes puede solicitar por escrito que se suspenda el procedimiento judicial, mientras las partes tratan de resolver el conflicto mediante un mecanismo de resolución alternativa de controversias. En ese caso, si existe desacuerdo de la otra parte, el juez está facultado para ordenar dicha suspensión y someter a las partes a mediación, si estima que concurre un "razonable fundamento".

${ }^{42}$ Así por ejemplo, el apartado II de las "Reglas Anexas de la Corte para la Mediación de Litigación Civil” del Estado de Mississippi, EE.UU., establece lo siguiente: Casos apropiados para remitir a mediación. Todos los casos civiles deberán considerarse apropiados para remitir a mediación a discreción de la Corte, tomando en cuenta ciertos hechos como el asunto del caso, el monto en controversia, la complejidad del caso, el número de partes, el interés de las partes en avanzar y proseguir a la mediación, la disponibilidad de mediación, y la probabilidad de arreglo por mediación (traducción libre del autor).

${ }^{43}$ La figura nos parece cuestionable, pues el mediador debe ser un tercero imparcial por antonomasia, sin relaciones de interés que lo vinculen con cualquiera de las partes del conflicto. Sin embargo, en este caso y tratándose de prestadores de salud públicos, el papel de mediador se asigna ex lege al Consejo de Defensa del Estado, organismo que, eventualmente, será precisamente el que represente judicialmente a la entidad 
de servicios de salud allí mencionados (art. 43 inc. $1^{\circ}$ ), para luego asignarle al acuerdo los efectos de un contrato de transacción (art. 53).

\section{B) Mediación voluntaria}

En un sistema de entera voluntariedad, en cambio, la ley debe contemplar expresas disposiciones tendientes a garantizar el eventual cumplimiento compulsivo del acuerdo, ya sea por la vía de regular algún mecanismo de homologación judicial del mismo o, simplemente, confiriéndole mérito ejecutivo al Acta que contenga dicho acuerdo. Cada una de estas alternativas ha sido recogida precisamente por el derecho chileno, como se dirá infra, aunque no en el ámbito del conflicto patrimonial.

Ejemplo de un sistema de acuerdo homologado, en cambio, es el que regula la ley española 5/2012 y que, pese a su cualidad esencialmente contractualista ${ }^{44}$, admite también la posibilidad de que un acuerdo de mediación surgido durante un proceso civil ya iniciado pueda ser incorporado al mismo y homologado por el juez como equivalente jurisdiccional $^{45}$. Dicha posibilidad, sin embargo, no cambia el origen contractual del acuerdo, pues, como ha dicho allí la jurisprudencia, lo que muta con la homologación no es la esencia del mismo, sino son solo sus efectos ${ }^{46}$. Por esta razón, la señalada homologación judicial no constituye verdaderamente una excepción a la regla general del art. 23.4 de la ley, que fija el ámbito sustantivo de impugnación del acuerdo ${ }^{47}$, pues la

pública de salud demandada, de no llegarse a un acuerdo en la sede previa de mediación que, como se acaba de señalar, se realiza ante él mismo.

Respecto de los sistemas comparados de mediación en el ámbito sanitario puede consultarse a CAYón DE las Cuevas, Joaquín, "Resolución extrajudicial de conflictos sanitarios: Manifestaciones jurídico-positivas y posibilidades de futuro", en García Villaluenga et al., Mediación, arbitraje y resolución extrajudicial de conflictos en el siglo XXI. Madrid, Reus, 2010, pp. 293 y ss. Acerca del sistema chileno, véase a MirandA SuÁreZ, F., "La mediación prejudicial obligatoria de daños en salud. La experiencia de Chile", en ANDrOHER Biosca, S. y De Montalvo JäÄskeläinen, F. (dir.), Los avances del derecho ante los avances de la medicina. Cisur Menor, Thomson Aranzadi, 2008, pp. 327 y ss.

${ }^{44}$ Claro en este sentido es el art. 23.4, al señalar que Contra lo convenido en el acuerdo de mediación solo podrá ejercitarse la acción de nulidad por las causas que invalidan los contratos.

${ }^{45} \mathrm{El}$ art. 25.4 de la Ley $\mathrm{N}^{\circ}$ 5/2012 establece: 4. Cuando el acuerdo se bubiere alcanzado en una mediación desarrollada después de iniciar un proceso judicial, las partes podrán solicitar del tribunal su bomologación de acuerdo con lo dispuesto en la Ley de Enjuiciamiento Civil. Por su parte, el art. 415.2. de la LEC, del año 2000, señala que El acuerdo bomologado judicialmente surtirá los efectos atribuidos por la ley a la transacción judicial y podrá llevarse a efecto por los trámites previstos para la ejecución de sentencias y convenios judicialmente aprobados. Dicho acuerdo podrá impugnarse por las causas y en la forma que se prevén para la transacción judicial; mientras que el art. 26 inc. $1^{\circ}$ de la Ley $\mathrm{N}^{\circ}$ 5/2012 precisa que La ejecución de los acuerdos resultado de una mediación iniciada estando en curso un proceso se instará ante el tribunal que homologó el acuerdo.

46 Por todas, STS español, de 5 de abril de 2010, rec. 2371/2005: La transacción procesal tiene una naturaleza dual, ya que, manteniendo su carácter sustantivo, la aprobación judicial le confiere un carácter procesal como acto que pone fin al proceso, con el efecto de hacer posible su ejecución como si se tratara de una sentencia (arts. 1816 CC y 517.3 LEC).

47 Así lo ha dicho también la jurisprudencia. Por todas, STS español, de 8 de julio de 1999, rec. 3614/1994: (...) la imposibilidad de replantear las cuestiones transigidas no implica que la transacción sea invulnerable, ya que puede impugnarse su validez y eficacia, dejándola sin efecto y reavivando la situación jurídica 
naturaleza dual del mismo no llega al extremo de renegar de su fuente originaria, como se acaba de señalar.

\section{La situación en el derecho chileno. Recapitulación}

Hemos dicho que la legislación chilena, ausente en materia de mediación de asuntos patrimoniales, ha optado por incorporarla en cambio en otros ámbitos jurídicos de manera más o menos prolija, como ocurre con la mediación en materia de familia y de algunos conflictos en los que intervienen prestadores de servicios de salud. En otros casos, la ley confunde incluso la mediación con la conciliación, al conferirle al "mediador" facultades para presentar propuestas de solución e incluso para recabar información de entes privados y públicos, como ocurre por ejemplo con la mediación laboral regulada en los arts. 352 a 345 del Código del Trabajo.

En lo que concierne concretamente a la ejecución del acuerdo de mediación, la ley chilena, cuando se ha ocupado de ello, sigue básicamente las mismas directrices mencionadas supra, dependiendo de si el modelo escogido es uno que opera de manera conectada y complementaria al proceso judicial, con un acuerdo de mediación considerado como equivalente jurisdiccional (caso de la Ley $\mathrm{N}^{\circ} 19.698$ en materia de familia); o enteramente independiente del proceso civil, con un acuerdo de mediación de naturaleza enteramente contractual, en su fuente y en sus efectos (caso de la Ley $\mathrm{N}^{\circ} 19.966$, en materia de conflictos surgidos en el ámbito de las prestaciones de salud).

Queda por definir, entonces, el modelo de mediación a seguir en el ámbito del conflicto patrimonial, comercial o civil, de cara a una futura -y esperamos que próximaregulación legal de la materia. Para abordar esa tarea, un factor relevante a considerar radica en la muy escasa información que manejan los agentes del conflicto en el medio nacional, pese a la percepción mayoritariamente favorable que tienen a su vez respecto de la mediación. Tal circunstancia explica, acaso como razón principal, que las empresas y sus abogados opten por no utilizar este mecanismo al momento de surgir el conflicto, fenómeno que han debido abordar también en su momento las legislaciones comparadas más desarrolladas en esta materia ${ }^{48}$.

En Chile, sin embargo, no existen datos empíricos suficientes con los que se pueda construir una regulación legal que se ajuste a las necesidades y características del conflicto patrimonial, en sus aspectos jurídicos, económicos e incluso sicológicos o de relaciones interpersonales, carencia que no hace más que incrementar - por contrapartida- los

anterior. La interpretación del artículo 1816 CC ha de hacerse sin mengua de la naturaleza contractual propia de la transacción.

48 Referente a este aspecto, en el ámbito europeo comunitario se puede consultar la investigación denominada The Cost of Non ADR-Surveying and Showing the Actual Costs of Intra-Community Commercial Litigation (2010), financiada por la Unión Europea e implementada por el $A D R$ Center, en colaboración con la European Company Lawyers Association (ECLA) y la European Association of Craft, Small and Medium-Sized Enterprises (UEAPME). 
altos índices de litigiosidad que exhibe el país en el ámbito latinoamericano ${ }^{49}$. Frente a este escenario, durante junio del 2016 optamos por realizar un amplio trabajo práctico orientado a recopilar una base mínima de información respecto de la mediación patrimonial en Chile, mediante encuestas dirigidas simultáneamente a empresarios, abogados y jueces. Los resultados de ese estudio, al que nos remitimos ${ }^{50}$, muestran que la falta de regulación legal de la mediación de asuntos comerciales y civiles en Chile constituye un obstáculo que impide el desarrollo de este mecanismo, al no existir una base mínima de principios jurídicos y de garantías procedimentales que traigan certeza, en lo que aquí concierne, al efectivo cumplimiento del acuerdo de mediación ${ }^{51}$. Del mismo modo, empresarios, abogados y jueces se mostraron ampliamente proclives a implementar un modelo de mediación obligatoria y conectada o anexa al proceso civil, como forma de ilustrar a los operadores del conflicto acerca de la mediación en sí misma y de sus ventajas como alternativa a la vía litigiosa ${ }^{52}$.

${ }^{49}$ Como se señala en el "Perfil de Proyecto" del Programa BID sobre "Apoyo a la Reforma Judicial", aprobado en julio de 2010, según el "Reporte Sobre la Justicia en las Américas del Centro de Estudios de Justicia de las Américas" (CEJA), Chile es el país de América Latina con la tasa más alta de litigiosidad, con un ingreso anual de causas que sigue aumentando (Proyecto BID N ${ }^{\circ}$ CH-L1058, "Perfil de Proyecto", p. 1. Disponible en: http://idbdocs.iadb.org/wsdocs/getdocument.aspx?docnum=35080924).

${ }^{50}$ Las encuestas fueron respondidas por un universo total de 749 personas, de estas, 334 completaron la encuesta en su totalidad (JEQUIER, "Estudio práctico sobre la mediación de asuntos civiles y comerciales y su vinculación con el proceso civil en Chile. Resultado de encuestas dirigidas a abogados, jueces y emprendedores y empresarios chilenos (junio-julio de 2016)", en proceso editorial, Revista de Derecho Pontificia Universidad Católica de Valparaíso.

${ }^{51}$ Los datos obtenidos muestran que, en general, los empresarios son proclives a buscar una solución negociada directa del conflicto -no necesariamente mediación-, con 51,4\% que asegura explorar siempre o casi siempre esa vía. Del porcentaje restante, solo 30\% dijo no haberlo intentado. En el caso de los abogados, el porcentaje es del 40,7\% (siempre o casi siempre), mientras que solo el 14,8\% no lo había hecho nunca. Tratándose concretamente de la mediación, la mayoría de los abogados $(68,8 \%)$ dijo no tener ninguna experiencia al respecto, o una muy incipiente (en una o dos ocasiones). No obstante, el 36,5\% de ellos señaló que siempre o casi siempre recomienda a sus clientes incluir en los contratos una cláusula de mediación, posibilidad que en general calificaron con nota 5,1 y los empresarios con nota 5,3 (de 1 a 7). Sin embargo, el $91,7 \%$ de los abogados reconoció al mismo tiempo que, ante un conflicto ya existente, no recomienda a sus clientes la posibilidad de someterlo a mediación, debido a la incertidumbre que genera la falta de regulación de cara a la efectiva ejecución de lo acordado (ibid.).

52 En este sentido, $79 \%$ de los jueces encuestados dijo estar de acuerdo y muy de acuerdo con el modelo de mediación obligatoria previa y conectada al proceso civil. El $72 \%$ de los encuestados consideró, a su vez, que la determinación de los casos que deben derivarse a mediación, antes o durante el proceso civil, debe ser una facultad del juez. El $52 \%$ de los encuestados sostuvo que todos los conflictos empresariales deben someterse a mediación previa obligatoria, y el $67 \%$ consideró jurídicamente legítima la medida de imponer la mediación previa obligatoria. Una posición intermedia fue planteada por el $75 \%$ de los encuestados, quienes postularon la alternativa de una sesión previa obligatoria de mediación, de carácter informativo, de manera que sean las partes quienes opten por someterse -o no- a un procedimiento de mediación; y todo sin perjuicio de la facultad del tribunal, antes referida (ibid). 


\section{CONCLUSIONES}

1. En cuanto a la necesidad de una reforma legislativa que introduzca las bases de un procedimiento de mediación en el ámbito patrimonial en Chile.

A) Es indispensable, en primer término, que en Chile se regule legalmente la mediación de asuntos mercantiles y civil/patrimoniales, con miras a potenciarla -o acaso rescatarla- en cuanto mecanismo de solución rápida y de bajo costo para un importante número de conflictos empresariales, en los que el cauce jurisdiccional resulta ineficiente e incluso económicamente inviable. En esa tarea, además, y en lo que a este trabajo concierne, la definición del modelo a seguir resulta determinante de cara a la ejecución del acuerdo de mediación, existiendo extremos que van desde la completa voluntariedad de la mediación -caso español- hasta su total obligatoriedad -como el caso argentino-.

B) La falta de regulación legal de la mediación patrimonial en Chile repercute directamente en los mecanismos de ejecución del acuerdo de mediación, que por surgir en contextos desregulados o de mediación ad hoc, debe asimilarse a otras figuras jurídicas que desdibujan la naturaleza de la mediación, vista como institución autónoma.

2. En cuanto a los mecanismos a partir de los cuales debe regularse la ejecución obligatoria de los acuerdos de mediación en asuntos patrimoniales.

Tomando como base los datos estadísticos obtenidos durante el 2016, la inexperiencia y la falta de información acerca de la mediación patrimonial que se observa entre los agentes del conflicto, generadoras - a su vez- de desconfianzas de cara a su real eficacia y a la posibilidad cierta de obtener el cumplimiento de lo acordado, justifican la implementación de un modelo de mediación obligatoria e incluso previa, conectada o anexa al procedimiento civil, en donde el acuerdo de mediación constituya un equivalente jurisdiccional ejecutable como sentencia. Especial atención se debe poner, además, en la implementación de mecanismos que incentiven la colaboración y buena fe de las partes, durante el procedimiento de mediación, imponiendo sanciones pecuniarias que en los sistemas comparados van desde la aplicación de multas (alternativa que no nos parece idónea) hasta la obligación de pagar los gastos del procedimiento de mediación, incluidos los honorarios del mediador y los del abogado de la contraparte.

\section{BIBLIOGRAFÍA}

Alessandri Rodríguez, A., De los Contratos, Santiago, Editorial Jurídica Ediar Conosur Ltda., 1988.

Álvarez Moreno, M. T. (2000): "La Mediación empresarial", en Revista de Derecho Privado (2000), pp. 959-986.

Álvarez Torres, Manuel; Gil Vallejo, Beatriz; Morcillo Jiménez, Jesús (2013): Mediación civil y mercantil (Madrid, Dykinson). 
Barona Vilar, Silvia, Mediación en asuntos civiles y mercantiles en España. Valencia, Tirant lo Blanch, 2013.

Bergin, P. A., "The Objectives, Scope and Focus of Mediation Legislation in Australia", conferencia presentada en el congreso internacional "Mediation First", organizado por el "Hong Kong International Arbitration Centre" y el "Hong Kong Mediation Council”. Hong Kong, 11 de mayo de 2012. Disponible en: http://www.austlii.edu.au/au/journals/NSWJSchol/2012/24. pdf (consultado el 23 de marzo de 2017).

Blanco Carrasco, Marta, Mediación y sistemas alternativos de resolución de conflictos. Madrid, Reus, 2009.

Castillejo Manzanares, Raquel, "El acuerdo de mediación”, en Castillejo Manzanares, Raquel (dir.), Comentarios a la Ley $N^{\circ}$ 5/2012, de mediación de asuntos civiles y mercantiles. Valencia, Tirant lo Blanch, 2015.

Cayón de las Cuevas, Joaquín, "Resolución extrajudicial de conflictos sanitarios: Manifestaciones jurídico-positivas y posibilidades de futuro", en García Villaluenga, Leticia (et al.,), Mediación, arbitraje y resolución extrajudicial de conflictos en el siglo XXI. Madrid, Reus, 2010. Dupuis, Juan Carlos, Mediación y Conciliación. Buenos Aires, Abeledo Perrot, 2001.

FIsher, Roger y URY, William, ";Sí, de acuerdo! Cómo negociar sin ceder (2 $2^{\mathrm{a}}$ ed., $4^{\mathrm{a}}$ reimpresión). Bogotá, Norma, 1993.

García Villaluenga, Leticia y Rogel Vide, Carlos (dir.), Mediación en asuntos civiles y mercantiles. Comentarios a la Ley No 5/2012. Madrid, Reus, 2012.

García Villaluenga, Leticia y Vázquez de Castro, Eduardo, "La mediación civil en España: luces y sombras de un marco normativo", en Política y Sociedad (Vol. 50, No 1), 2013.

Herrera de las Heras, Ramón, "La mediación obligatoria para determinados asuntos civiles y mercantiles", en Revista InDret ( $\left.\mathrm{N}^{\circ} 1-2017\right)$.

Hualde Manso, Teresa (dir.), La mediación en asuntos civiles y mercantiles: la transposición de la Directiva 2008/52 en Francia y en España. Madrid, La Ley, 2013.

Jequier Lehuedé, Eduardo, "La mediación como alternativa de solución de los conflictos empresariales en Chile. Razones y mecanismos para su regulación”, en Revista de Derecho (Valdivia). Universidad Austral de Chile, Vol. XXIX, No 1, junio 2016.

López Jara, Manuel, "Incidencia del Nuevo procedimiento de mediación en el proceso civil. A propósito del Real Decreto-Ley $\mathrm{N}^{\circ} 5 / 2012$, de 5 de marzo, de mediación en asuntos civiles y mercantiles”, en Diario La Ley, Sección Doctrina ( $\mathbf{N}^{\circ} 7857,14$ de mayo de 2012, año XXXIII, Ref. D-199), 2012.

López Simó, Francisco y Garau Sobrino, Federico (coord.), Mediación en materia civil y mercantil. Valencia, Tirant lo Blanch, 2014.

Magro Servet, V., "Análisis sobre medidas necesarias de desarrollo legal y reglamentario de la Ley $\mathrm{N}^{\circ}$ 5/2012 de mediación civil y mercantil para el éxito del sistema”, en Práctica de Tribunales ( $\mathrm{N}^{\circ}$ 2254-948X), marzo de 2013.

Martí Mingarro, L., "La mediación civil y mercantil en la nueva Ley $\mathrm{N}^{\circ}$ 5/2012, de 6 de julio", en Revista jurídica de Castilla y León, $\mathrm{N}^{\circ}$ 29, 2013.

Miranda SuÁrez, F, "La mediación prejudicial obligatoria de daños en salud. La experiencia de Chile”, en Androher Biosca, S. y De Montalvo Jääskeläinen, F. (dir.), Los avances del derecho ante los avances de la medicina. Cisur Menor, Thomson Aranzadi, 2008.

SÁnChez Hernández, Raquel, "Procedimiento y ejecución de acuerdos”, en Boldó Roda, Carmen (dir.), La mediación de asuntos mercantiles. Valencia, Tirant lo Blanch, 2013.

SENÉs Motilla, Carmen, "El acuerdo de mediación y su ejecución”, en López Simó, F. y Garau Sobrino, F. (coord.), Mediación en materia Civil y mercantil. Valencia, Tirant lo Blanch, 2014. 
